\title{
Customer Satisfaction Analysis of Online Taxi Mobile Apps
}

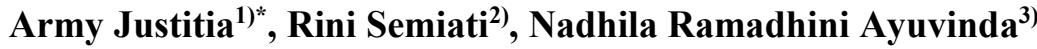 \\ 1)233) Information Systems, Universitas Airlangga, Indonesia \\ Kampus C Mulyorejo, Surabaya \\ ${ }^{1)}$ army-j@fst.unair.ac.id, ${ }^{2)}$ rini-s@fst.unair.ac.id, ${ }^{3)}$ nadhilaayuvinda-14@fst.unair.ac.id
}

Article history: Abstract

Received 18 February 2019 Revised 6 April 2019

Accepted 11 April 2019

Available online 28 April 2019

Keywords:

Customer Satisfaction Customer Satisfaction Index Importance Performance Analysis Online Taxi Mobile App

Strategic Planning

\begin{abstract}
Background: High number of complaints that have been filed about the performance of online taxi services has prompted research on customer satisfaction factor analysis. Substantial research has addressed customer satisfaction factors in online taxi services, but none of them investigated the satisfaction in using the mobile apps.

Objective: This study aims to find out the level of customer satisfaction and customer satisfaction factors in the online taxi mobile app services.

Methods: This study is quantitative in nature, using questionnaires and purposive sampling method. The Customer Satisfaction Index (CSI) and Important-Performance Analysis (IPA) were used to determine the customer satisfaction factors, with the variables being route detection, connection, interaction, content, and service quality; as well as customer satisfaction, customer's complaint, and customer loyalty. The data was processed using SPSS software.

Results: The results showed that the level of customer satisfaction was $76.117 \%$ and fell into Cause of Concern category. This means that the system performance did not meet customer expectations. The results also showed that the best three factors in online taxi mobile apps are route detection, interaction, and content quality. Meanwhile, the factors that caused customer dissatisfaction were connection and service quality. The variables that led to satisfaction need to be maintained and the variables that did not were in Quadrant 1.

Conclusion: The customer satisfaction was low so it is advisable that the companies immediately take an action to improve their performance and revise their strategic planning. In doing so, they must prioritize the attributes which have the biggest gap because these are the ones that will improve customer satisfaction.
\end{abstract}

\section{INTRODUCTION}

Rapid growth in digital businesses has provided many conveniences, one of which is the modes of transportation [1]. Nowadays, online transportation services are widely available both motorcycles and cars. Online taxi services, also known as ride-sharing, allows customers to book a car through a mobile app [2]. This has become one of the phenomenal startup businesses in Indonesia since 2015 [3]. Go-Car, GrabCar, UberX and MyBluebird are the most popular online taxi providers. They have the largest market share and are thriving in the fierce competition of the service industry [4].

Customer satisfaction is a major issue for organizations or companies in today's highly competitive market [5]. It is important for a company to improve the quality of service, products, and customer loyalty in order to survive in the competitive market [6]. Yayasan Lembaga Konsumen Indonesia (YLKI) reported that customers still complained about the poor performance of online taxi mobile apps, such as the system error, double order, inaccurate location, and confusing menu display [7]. An evaluation of service quality is needed to increase customer satisfaction and loyalty.

CSI is a measure of overall service satisfaction. It is an index to determine the overall level of user satisfaction by taking into consideration the measured attributes' level of importance [8]. However, CSI cannot measure the performance of services from the point of view of customers. If the system service performance does not meet customer expectations, customer satisfaction will decrease. The greater the difference between performance and expectations, the lower the customer satisfaction. One measurement of service performance is the Importance Performance Analysis (IPA), which works by comparing user ratings based on the importance of service quality and the service performance. IPA has been widely used in many studies because of its easy operation and its efficient analysis display that is suitable for proposing improvements [9].

\footnotetext{
${ }^{*}$ Corresponding author
} 
This study aims to find out the customer satisfaction in online taxi mobile app services and identify the influence of customer satisfaction on the development of company strategic planning. We limit this research for online taxi customers in Surabaya, Sidoarjo and Gresik areas. The results of CSI indicate the level of customer satisfaction, which provide feedback to improve service quality. The results of IPA do not only show the level of satisfaction but also the dissatisfaction. With this, taxi companies can formulate solutions so that their customer satisfaction match with the expectations..

\section{II.LITERATURE REVIEW}

\section{A. Customer Satisfaction Factor in Online Taxi Mobile App}

Satisfaction is found when one's expectations match with the product/service's perceived performance [8], [10]. Loyalty is earned when a customer repurchase a service/product or recommend it to a new potential customer [11]. Customer satisfaction has a direct positive correlation with loyalty [11]. Satisfied customers are loyal customers.

Online taxi mobile app is a value-added service provider that utilizes mobile technology [12]. Chae proposed that the criteria for the information quality of mobile-based services are: connection, content, and interaction quality [13]. Good connection quality means that users rarely experience errors and stable networks are maintained. Content quality is whether or not content is complete, correct, urgent and up-to-date [12]. Interaction quality means good app appearance and menu structure and user-friendly navigation. Kuo argues that IT-based service providers must response fast and must have rapid compliance responses and Frequently Asked Question (FAQ) features so that customers can easily and quickly find solutions to their common problems [12], [14].

Another feature that makes a good online taxi mobile app is the ability to make estimation such as the destination location, the distance and travel time, as well as the fleet availability[15]. Customers need assurance, especially whether or not they are going to get the ride. Therefore, application needs a feature that displays the fleet availability in real time. Online taxi mobile app must be equipped with a detection facility that shows available vehicle in the closest proximity. Other things being equal, each of these factors will contribute to the overall customer satisfaction. Satisfaction affects loyalty and make customers return and repurchase [16].

\section{B. Customer Satisfaction Index}

Customer Satisfaction Index (CSI) is a measurement of the overall level of customer satisfaction by considering the variable interest and the attributes of the service/product [8]. Customer satisfaction level can be determined by comparing CSI indicator values against user's expectations [17]. Research by Utomo et al. formulated a scheme to describe the levels of satisfaction [18] as presented Table 1 below:

TABLE 1

CUSTOMER SATISFACTION INDEX INTERPRETATION

\begin{tabular}{lc}
\hline \hline \multicolumn{1}{c}{ Index Range } & Interpretation \\
\hline $\mathrm{X} \leq 64 \%$ & Very Poor \\
$64 \%<\mathrm{X} \leq 71 \%$ & Poor \\
$71 \%<\mathrm{X} \leq 77 \%$ & Cause of Concern \\
$77 \%<\mathrm{X} \leq 80 \%$ & Borderline \\
$80 \%<\mathrm{X} \leq 84 \%$ & Good \\
$84 \%<\mathrm{X} \leq 87 \%$ & Very Good \\
$87 \%<\mathrm{X}$ & Excellent \\
\hline
\end{tabular}

\section{C.Importance-Performance Analysis}

Importance Performance Analysis (IPA) measures perceived performance based on the importance of service with a two-dimensional plot [19]. IPA can be used to formulate and improve management strategies [20]. IPA is widely used to evaluate user satisfaction in tourism, culinary business, education, healthcare, banking, public administration, e-business and information technologies [21].

Setiawan [22] describes the data processing steps of using IPA. After getting the IPA value, Cartesian plot is determined. Cartesian plot will classify attributes into four quadrants so that they can be sorted into resource allocation priorities. The illustration is presented in Fig. 1.

The attributes in Quadrant I score high in importance level for customers but score low in performance which means that they do not meet customer expectations. These attributes need more attention so management must concentrate here. The attributes in Quadrant II score high in importance and performance. Customers are very satisfied so the company must keep up the good work. The attribute characteristics in Quadrant III score low in importance and performance. The company does not need to prioritize these attributes because increasing performance will not increase satisfaction. The attributes in Quadrant IV score low in importance but high in 
performance. The company needs to reconsider resources allocation to the attributes in this quadrant or to relocate them to the more important attributes.

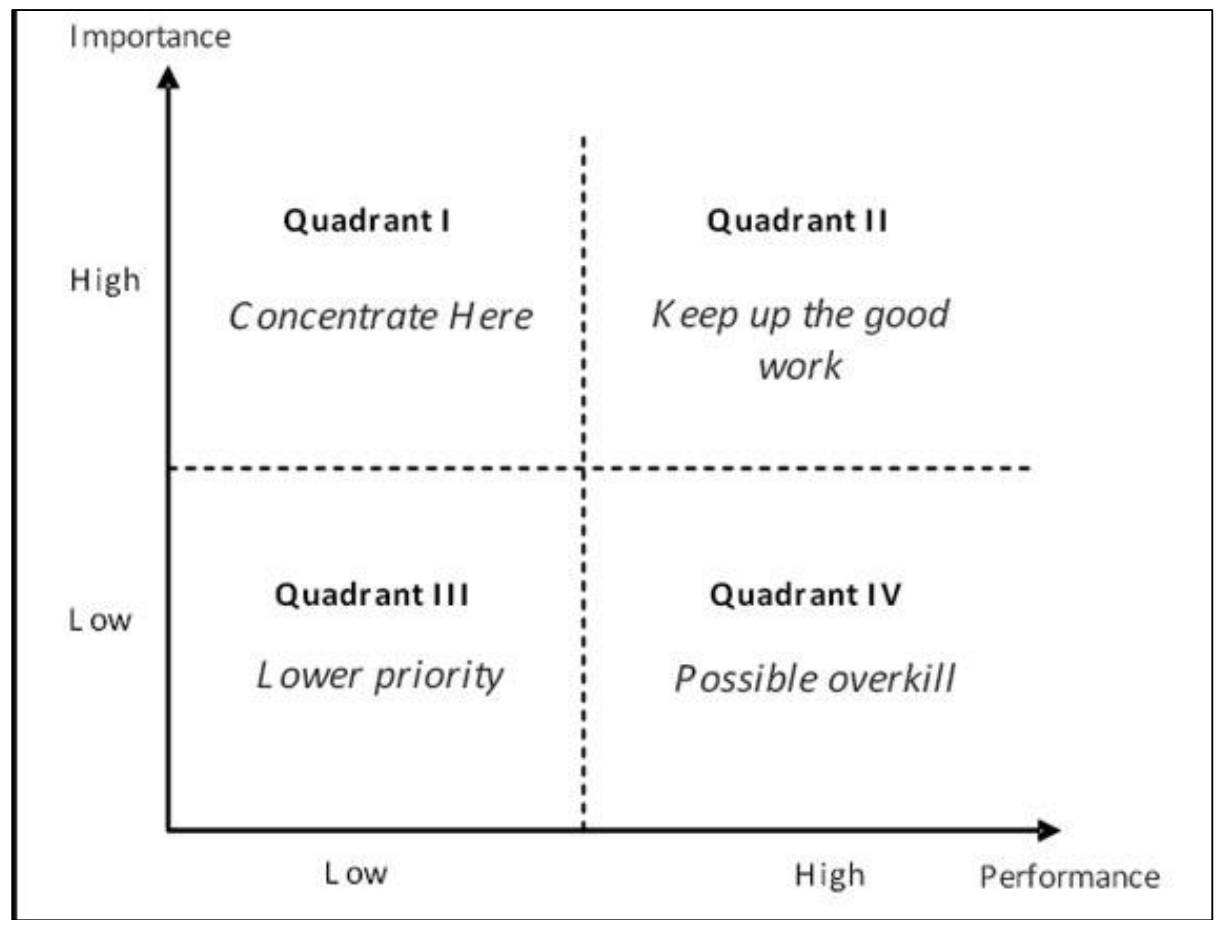

Fig. 1 Importance-Performance Matrix (Adapted from[19])

\section{METHODS}

There are six steps to conduct this research, summarized as follows:

\section{A. Defining variables and attributes}

There were eight variables used to measured customer satisfaction, namely route detection quality, connection quality, interaction quality, content quality, service quality, customer satisfaction, customer complaint and customer loyalty. We broke down each variable into several attributes to specify what factors influence customer satisfaction. The variables and attributes used in this study is presented in Table 2.

\section{B. Defining population and sample}

The respondents were online taxi mobile app users and were at least 17 years old. They were chosen using purposive sampling. Since the total population of respondents was unlimited, sample was obtained using the equation formulated by Isaac Michel [23]. With a confidence level of 95\% and error margin of 5\%, the total sample was 384 respondents.

\section{Constructing and distributing the questionnaire}

The questionnaires consisted of 23 questions covering all the measured attributes. The measurement was a 6point-Likert-type scale. They were distributed offline by giving out directly to randomly chosen respondents, and online through Google Form.

\section{D.Testing the measuring attributes}

\section{Validity Test}

Validity test was conducted to ensure that the items in the questionnaire were valid to measure the targeted variables [24]. The higher the validity value, the more valid the questions and the attributes are.

Pearson correlation test was used to test the validity. Attributes are considered valid if they have a minimum coefficient of 0.3 [25]. If the correlation value is more than the minimum coefficient, then the attribute is considered valid. 
TABLE 2

VARIABLES AND ATTRIBUTES OF THIS STUDY

\begin{tabular}{|c|c|c|c|}
\hline Variables & & Measured Attributes & $\begin{array}{l}\text { Related } \\
\text { Studies }\end{array}$ \\
\hline \multirow[t]{4}{*}{ Route Detection Quality } & $\mathrm{Pd} 1$ & The application can display the availability of the nearest driver fast & \multirow{4}{*}[13]{} \\
\hline & $\mathrm{Pd} 2$ & Display the accuracy of destination & \\
\hline & $\mathrm{Pd} 3$ & Estimate mileage to the destination & \\
\hline & $\mathrm{Pd} 4$ & Estimate travel time to the destination & \\
\hline \multirow[t]{3}{*}{ Connection Quality } & Kn1 & Online taxi mobile application is stable & \multirow{3}{*}[11]{} \\
\hline & $\mathrm{Kn} 2$ & The application server runs without error & \\
\hline & $\mathrm{Kn} 3$ & Scanning and searching location run smoothly and quickly & \\
\hline \multirow[t]{3}{*}{ Interaction Quality } & In1 & The interface is clear and easy to understand & \multirow{3}{*}[11]{} \\
\hline & In 2 & Menu, contents, and interface design are consistent and harmonious & \\
\hline & In 3 & The navigation panel is easy to use and it is easy to return to the main menu & \\
\hline \multirow[t]{4}{*}{ Content Quality } & Ko1 & The content is accurate & \multirow{4}{*}[10]{} \\
\hline & Ko2 & The content is up-to-date & \\
\hline & Ko3 & The content is helpful & \\
\hline & Ko4 & The content is clear and easy to understand & \\
\hline \multirow[t]{3}{*}{ Service Quality } & La1 & Fast response to user requests & \multirow{3}{*}[10]{,$[12]$} \\
\hline & $\mathrm{La} 2$ & Adequate Frequently Asked Question (FAQ) & \\
\hline & La3 & Customer complaints are responded quickly & \\
\hline \multirow[t]{3}{*}{ Customer Satisfaction } & Kep1 & Overall satisfaction of application services & \multirow{3}{*}[14]{} \\
\hline & Kep2 & High level of synchronization between passenger and driver & \\
\hline & Kep3 & Suitability between performance and customer expectations & \\
\hline Customer Complaint & Kel1 & There are still complaints regarding application services & {$[14]$} \\
\hline \multirow[t]{2}{*}{ Customer Loyalty } & Lo1 & Customers want to reuse the application & \multirow{2}{*}[14]{} \\
\hline & Lo2 & Customers want to recommend application services to others & \\
\hline
\end{tabular}

\section{Reliability Test}

According to Indrawati [24], reliability is the level of trustworthiness, consistency, or stability of the results of a measurement. Reliability is the extent to which the results of a measurement can be trusted or to what extent the measurement results are free from errors. One common technique to measure instrument reliability is the Cronbach's Alpha technique, which considers an instrument reliable if the coefficient is $>0.70$.

\section{E. Data processing using CSI and IPA}

Data obtained from the questionnaire was then processed using CSI and IPA, assisted by SPSS Software. CSI was used to determine the level of overall user satisfaction. Meanwhile, IPA was used to compare the importance of services to service performance.

\section{F. Interpretation and results analysis}

The results analysis shows that there were differences in perceived performance and customer expectations in each variable. The analysis is organized by using Cartesian diagram to order the repair priorities.

\section{RESUlts}

\section{A. Data Collection}

The respondents were online taxi mobile apps users, namely Grab, Uber, Go-Car and MyBluebird. Data was collected from 20 January 2018 to 6 March 2018, in three cities i.e. Surabaya, Sidoarjo and Gresik. The number of respondents was 417 , with 384 completing the questionnaire online and 33 offline. There were 384 valid data and 33 invalid data because the respondents had never used an online taxi mobile app. No bias data was found. Respondents' demographic profile included gender, age, occupation, and the frequency of using online taxi mobile apps. The distribution of respondents' demographic can be seen in Table 3.

There were more women using online taxi mobile app than men with the percentage of $73 \%$ and $26 \%$ respectively. Women seemed to prefer using public transportation rather than driving a motorbike or a car [4], [26]. Research conducted by Duchene [27] also found that there were fewer women owning a vehicle than men. However, women seemed to have traveled more often than men, for example to take children to school, go shopping, and go to work.

Age-wise, people aged 20-24 years were the most avid users at almost $88 \%$. Silalahi [4] argued that people at this age range, commonly referred to as millennials generation, were able to adapt quickly to technological development. Based on the employment status, students made up the majority ( $83 \%)$. Students here means those in elementary school up to the doctoral degree. This result was in line with previous research [4] with the percentage of $75 \%$. Private employees were the second highest users, at $10 \%$, similar to that of in research [4], which was $15 \%$. 
TABLE 3

DISTRIBUTION OF RESPONDENTS DEMOGRAPHIC

\begin{tabular}{lcc}
\hline \hline \multicolumn{1}{c}{ Demographic feature } & $\mathrm{N}$ & $\%$ \\
\hline Gender & & \\
$\quad$ Male & 101 & 26.30 \\
$\quad$ Female & 283 & 73.70 \\
Age & & \\
$17-19$ & 22 & 5.73 \\
$20-24$ & 340 & 88.54 \\
$25-29$ & 6 & 1.56 \\
$30-34$ & 4 & 1.04 \\
$35-39$ & 6 & 1.56 \\
$\geq 40$ & 6 & 1.56 \\
Occupation & & \\
Student & 320 & 83.33 \\
Housewife & 2 & 0.52 \\
Civil servant / Government Officer & 13 & 3.39 \\
Private employee & 41 & 10.68 \\
Enterpreuner & 8 & 2.08 \\
Frequency using online taxi mobile app & & \\
$\quad<3$ times & 157 & 40.89 \\
3-5 times & 126 & 32.81 \\
$>5$ times & 101 & 26.30
\end{tabular}

Regarding frequency, most users (41\%) used the apps less than 3 times. The difference between subcategories in this category was between $4 \%$ and $8 \%$. In other categories, the difference among subcategories was very significant. The survey also showed that almost $50 \%$ users intended to reuse the online taxi mobile app.

\section{B. Instrument Testing Results}

Validity was tested by comparing Pearson correlation value with r-table [23]. If the value of Pearson correlation $>$ the value of $r$-table then the instrument is valid. Table 4 shows the validity test results for importance and performance. According to Azwar [25], validity test uses $r$-table with 0.05 levels of significance and $d f=(\mathrm{N}$ 2 ), with $\mathrm{N}$ showing the number of respondents. The $d f$ value in this study is 382 and the correlation value is 0.10 . Based on the correlation value per variable, all variable' correlation value is $>0.10$ and all variables are valid.

TABLE 4

VALIDITY TEST RESULTS FOR IMPORTANCE AND PERFORMANCE

\begin{tabular}{|c|c|c|c|c|c|}
\hline \multirow{2}{*}{ Attribute } & \multicolumn{2}{|c|}{ Correlation Value } & \multirow{2}{*}{ Attribute } & \multicolumn{2}{|c|}{ Correlation Value } \\
\hline & Importance & Performance & & Importance & Performance \\
\hline Pd1 & 0,732 & 0,708 & Ko3 & 0,711 & 0,730 \\
\hline $\mathrm{Pd} 2$ & 0,737 & 0,720 & Ko4 & 0,644 & 0,730 \\
\hline $\mathrm{Pd} 3$ & 0,784 & 0,705 & La1 & 0,721 & 0,740 \\
\hline $\mathrm{Pd} 4$ & 0,737 & 0,674 & $\mathrm{La} 2$ & 0,741 & 0,674 \\
\hline $\mathrm{Kn} 1$ & 0,556 & 0,720 & $\mathrm{La} 3$ & 0,637 & 0,592 \\
\hline $\mathrm{Kn} 2$ & 0,513 & 0,699 & Kep1 & 0,660 & 0,749 \\
\hline $\mathrm{Kn} 3$ & 0,624 & 0,715 & Kep2 & 0,575 & 0,723 \\
\hline In1 & 0,639 & 0,738 & Kep3 & 0,635 & 0,772 \\
\hline $\operatorname{In} 2$ & 0,684 & 0,701 & Kel1 & 0,557 & 0,386 \\
\hline In 3 & 0,657 & 0,716 & Lo1 & 0,587 & 0,682 \\
\hline Ko1 & 0,603 & 0,733 & Lo2 & 0,419 & 0,669 \\
\hline $\mathrm{Ko} 2$ & 0,748 & 0,708 & & & \\
\hline
\end{tabular}

Reliability is determined by the value of Cronbach's Alpha. A good reliability value must meet the Cronbach's Alpha criteria with the value above 0.70. The Cronbach's Alpha score from the analysis of importance and performance can be seen in Table 5 .

TABLE 5

RELIABILITY TEST RESULTS FOR IMPORTANCE AND PERFORMANCE

\begin{tabular}{lccc}
\hline \hline & Cronbach's Alpha & Cronbach's Alpha Based on Standardized Items & N of Items \\
\hline Importance & .934 & .938 & 23 \\
Performance & .950 & .952 & 23 \\
\hline
\end{tabular}

The value of Cronbach's Alpha for importance and performance are 0.934 and 0.950 respectively. With a value greater than 0.7 , the importance and performance items used in this study are reliable. 
TABLE 6

THE CSI RESULT

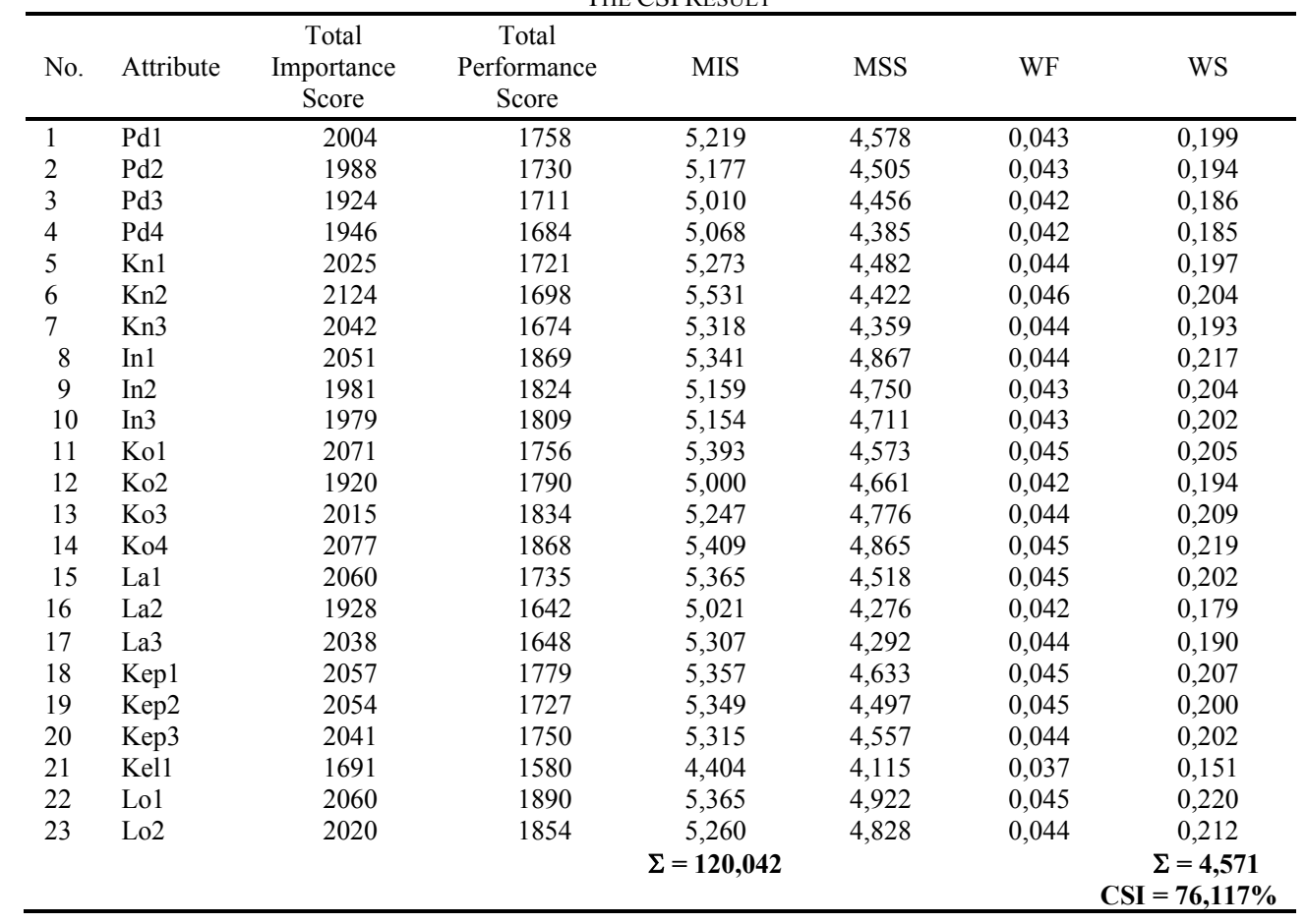

CSI was used to measure the level of overall user satisfaction by looking at the interests of variables and items from the online taxi mobile app services. Total Importance Score and Total Performance Score values are obtained by summing up the scale on each item given by all respondents. CSI value was calculated using the formula created by Utomo et al.[19]. The results of CSI calculations are presented in Table 6.

\section{The IPA Results}

TABLE 7

GAP ANALYSIS RESULTS

\begin{tabular}{ccccc}
\hline No. & Attribute & Importance & Performance & Gap Value \\
\hline 1 & Pd1 & 5.21 & 4.58 & -0.64 \\
2 & Pd2 & 5.18 & 4.51 & -0.67 \\
3 & Pd3 & 5.01 & 4.46 & -0.55 \\
4 & Pd4 & 5.07 & 4.39 & -0.68 \\
5 & Kn1 & 5.27 & 4.48 & -0.79 \\
$\mathbf{6}$ & Kn2 & $\mathbf{5 . 5 3}$ & $\mathbf{4 . 4 2}$ & $-\mathbf{1 . 1 1}$ \\
7 & Kn3 & 5.32 & 4.36 & -0.96 \\
8 & In1 & 5.34 & 4.87 & -0.47 \\
9 & In2 & 5.16 & 4.75 & -0.41 \\
10 & In3 & 5.15 & 4.71 & -0.44 \\
11 & Ko1 & 5.39 & 4.57 & -0.82 \\
12 & Ko2 & 5.00 & 4.66 & -0.34 \\
13 & Ko3 & 5.25 & 4.78 & -0.47 \\
14 & Ko4 & 5.41 & 4.86 & -0.54 \\
15 & La1 & 5.36 & 4.52 & -0.85 \\
16 & La2 & 5.02 & 4.28 & -0.74 \\
17 & La3 & 5.31 & 4.29 & -1.02 \\
18 & Kep1 & 5.36 & 4.63 & -0.72 \\
19 & Kep2 & 5.35 & 4.50 & -0.85 \\
20 & Kep3 & 5.32 & 4.56 & -0.76 \\
21 & Kel1 & 4.40 & 4.11 & -0.29 \\
22 & Lo1 & 5.36 & 4.92 & -0.44 \\
23 & Lo2 & 5.26 & 4.83 & -0.43 \\
& Average & 5.22 & 4.57 & \\
\hline
\end{tabular}

IPA was used to identify the attributes of online taxi mobile app services that needed improvement based on user assessments. Gap analysis was used to compare perceived performance and user expectations. The results of the gap analysis calculation can be seen in Table 7. Service quality is considered excellent if the gap value is greater than -1. From the table, it could be seen that overall service variables are considered good, except for Kn2 and $\mathrm{La} 3$. 


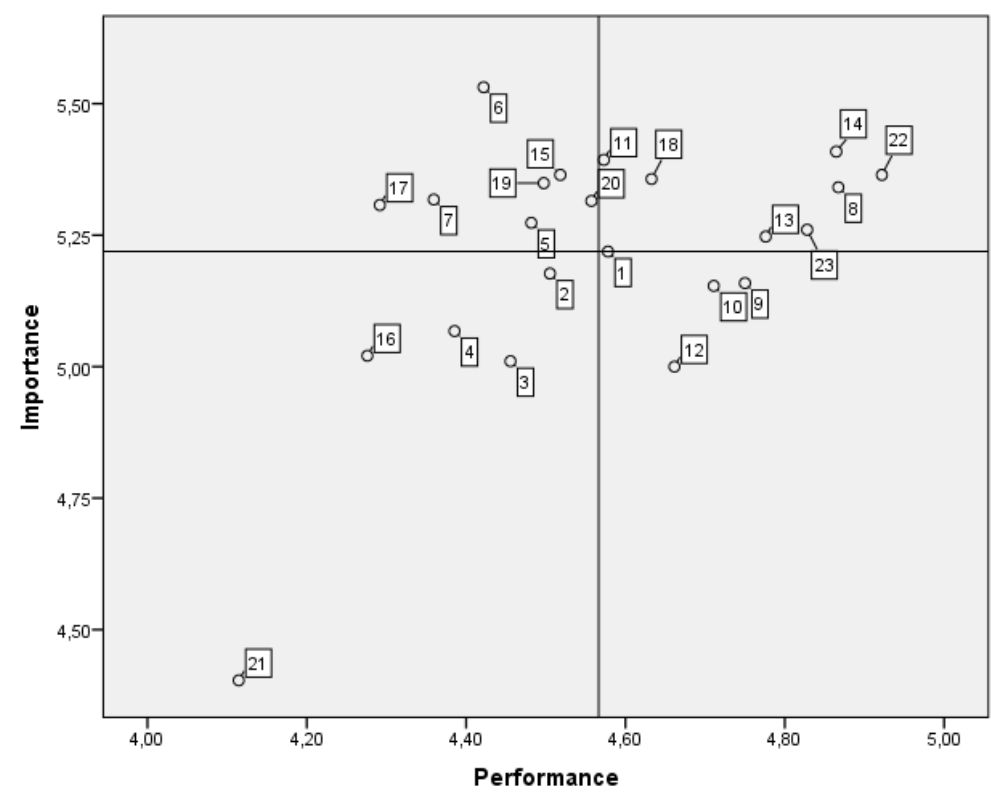

Fig. 2 Cartesian diagram of IPA on the quality of online taxi mobile app

The average value of performance and importance produced by the gap analysis then becomes the X-axis and Y-axis on the Cartesian Diagram. Each variable is mapped into 4-Quadrants. Fig. 2 shows the results of the Importance-Performance Analysis of all variables.

\section{DISCUSSION}

Table 7 shows that the CSI value is $76.117 \%$, which is categorized as Cause of Concern by the CSI Index [18]. The perceived performance is below customer expectation. Many customers were not satisfied with the online taxi mobile app service. It is important for the taxi companies to improve the performance because customer loyalty will help maintaining company's position in the highly competitive market [16].

Based on the gap analysis, low customer satisfaction was mainly caused by the frequent server errors (La2), slow scanning and searching of destination locations (Kn3), slow response to user request (La1), high level of synchronization between passenger and driver applications (Kep2), unstable app (Kn1) and a mismatch between customer performance and expectations (Kep3). The seven variables that have the highest analysis gap value were put into Quadrant I, Concentrate Here. Management needs to allocate resources and pay more attention to fix the problems here [19].

One example of synchronization problem was that a customer who had got a ride could be offered another ride by another driver. This means double services on the same reservation [7]. Customers also complained about unstable application performance, for example the maps and transportation options were gone, they could not log in, they failed to connect to the server, and they could not find a driver. The company actually provided a solution to frequently encountered problems in the help feature [28], but customers did not read it and immediately submitted their complaints. The customers' expectations did not match with the performance, leaving some gaps in the diagram.

Unstable applications, frequent server errors, and slow scanning and searching of destination locations may also have reduced the score for connection quality [13]. Actually, these problems were not entirely from the company. The company used large and reliable IT resources. It was the customer who did not use reliable technology that resulted in poor connection quality. Similar to the connectivity, customer complaint responses were poorly rated, which then reduced the service quality factors [12], [14]. Customers could file their complaints to the customer care of all online transportation companies, which provided various channels operating 24/7 e.g. call center, e-mail, social media or features in the application. The problem was that not all complaints were responded to and provided a solution. In fact, some complaints had no solution at all. They were not attended and then the same complaints were filed again.

Customers were satisfied with application services that displayed the availability of nearby fleets, that had clear and user-friendly interfaces, and that had accurate, helpful, up-to-date and understandable content. Overall, customers were satisfied with the application services, and they wanted to reuse and recommend to others [16]. Variables that contributed to the customer satisfaction were put into Quadrant II. 
The variables in Quadrant III were not too urgent. Customers felt that the performance was good, and it was not the most important feature to improve. For example, the inaccurate estimated travel time was tolerated by customers because it was affected by traffic jams so it could be unpredictable.

\section{CONCLUSIONS}

Customer satisfaction in online taxi mobile app services fell into Cause of Concern category with the value of $76.17 \%$. The online taxi mobile app companies must immediately provide solution in order to increase customer satisfaction. The IPA method classified problems into a diagram consisting of 4 quadrants and it showed that the main problems that required immediate solutions was in Quadrant 1. The variables that led to customer satisfaction were in Quadrant 2, and these must be maintained well. If companies intend to formulate their strategic planning, they must prioritize the attributes which have the biggest gap. These attributes require the most immediate attention and their improvement will significantly increase customer satisfaction.

\section{REFERENCES}

[1] D. M. Dahwilani, 'Pendapat Masyarakat Soal Layanan Taksi Online', Pendapat Masyarakat Soal Layanan Taksi Online, 17-Jul-2017. [Online]. Available: https://ekbis.sindonews.com/read/1221547/34/pendapat-masyarakat-soal-layanan-taksi-online-1500305167. [Accessed: 14-Nov-2018].

[2] G. S. Weng, S. Zailani, M. Iranmanesh, and S. S. Hyun, 'Mobile Taxi Booking Application Service's Continuance Usage Intention by Users', Transportation Research Part D : Transport and Environment, vol. 57, pp. 207-216, 2017.

[3] A. H. Pratama, 'Kilas Balik Perkembangan Ojek Online di Indonesia Sepanjang 2015', Kilas Balik Perkembangan Ojek Online di Indonesia Sepanjang 2015, Dec-2015. [Online]. Available: https://id.techinasia.com/kilas-balik-ojek-online-2015. [Accessed: 10Nov-2018].

[4] S. L. B. Silalahi, P. W. Handayani, and Q. Munajat, 'Service Quality Analysis for Online Transportation Services: Case Study of GOJEK', Procedia Computer Science 124, pp. 487-495, 2017.

[5] A. Poliaková, 'Application of the Customer Satisfaction Index (CSI) to Transport Services', vol. V, no. IV, pp. 208-215, 2010.

[6] C. O'Loughlin and G. Coenders, 'Application of the European Customer Satisfaction Index to Postal Services. Structural Equation Models versus Partial Least Squares', Departament d'Economia,Universitat de Girona, pp. 21-28, 2002.

[7] I. Wibowo, 'Survei YLKI: 40 Persen Pengguna Taksi Online Kecewa'. 2017.

[8] S. H. A. Syukri, 'Penerapan Customer Satisfaction Index (CSI) dan Analisis Gap pada Kualitas Pelayanan Trans Jogja', Jurnal Ilmiah Teknik Industri, vol. 13, pp. 103-111, 1 .

[9] B. C. Shia, M. Chen, and A. D. Ramdansyah, 'Measuring Customer Satisfaction Toward Localization Website by WebQual and Importance Performance Analysis (Case Study on AliexPress Site in Indonesia)', American Journal of Industrial and Business Management, vol. 6, no. 2, pp. 117-128, 2016.

[10] L. Eboli and G. Mazulla, 'A New Customer Satisfaction Index for Evaluating Transit Service Quality', Journal of Public Transportation, vol. 12 , no. 3, pp. 21-37, 2009.

[11] J. Allen, L. Eboli, C. Forciniti, G. Mazulla, and J. de D. Ortúzar, 'The role of critical incidents and involvement in transit satisfaction and loyalty', Transport Policy, vol. 75, pp. 57-69, Mar. 2019.

[12] Y.-F. Kuo, C.-M. Wu, and W.-J. Deng, 'The Relationships among Service Quality, Perceived Value, Customer Satisfaction, and Postpurchase Intention in Mobile Value-added Services', Computers in human behavior, no. 25, pp. 887-896, 2009.

[13] M. Chae and J. Kim, 'Information Quality for Mobile Internet Services: A Theoretical Model with Empirical Validation', ICIS 2001 Proceedings, vol. Paper 6, pp. 43-54, 2001.

[14] Y.-S. Wang and Y.-W. Liao, 'The Conceptualization and Measurement of M-Commerce User Satisfaction', Computers in Human Behavior, vol. 23, no. 1, pp. 381-398, Jan. 2007.

[15] L. P. Alexander and M. C. González, 'Assessing the Impact of Real-time Ridesharing on Urban Traffic using Mobile Phone Data', Proc. UrbComp, pp. 1-9, Aug. 2015.

[16] Y.-J. Park, P.-S. Heo, M.-H. Rim, and D.-S. Park, 'Customer Satisfaction Index Measurement and Importance-Performance Analysis for Improvement of the Mobile RFID Services in Korea', pp. 2657-2665, Jul. 2008.

[17] Z. Idris, 'Kajian Tingkat Kepuasan Pengguna Angkutan Umum di DIY', Dinamika Teknik Sipil vol 9 (2), pp. 189-196, 2009.

[18] W. H. Utomo, A. F. Wijaya, and C. A. Widi P, 'Customer Satisfaction Analysis to Health Service by SERVQUAL 5 Dimension Method and Customer Satisfaction Index', International Journal of Computer Applications, pp. 17-21, 2013.

[19] J. A. Martilla and J. C. James, 'Importance-Performance Analysis', Journal of Marketing, vol. 41, no. 1, pp. 77-79, 1977.

[20] Z. . Ali, I. Munira, N. R. . Suradi, and A. . Ismail, 'Importance-performance Analysis and Customer Satisfaction Index for Express Bus Services', Nature \& Biologically Inspired Computing, pp. 590-595, 2009.

[21] I. Sever, 'Importance-Performance Analysis: A valid management tool?', Tourism Management, vol. 48, pp. 43-53, 2015

[22] R. Setiawan, 'Analisa Tingkat Kepuasan Pengguna Kereta Api Komuter Surabaya - Sidoarjo', 2005.

[23] R. E. Walpole, R. H. Myers, S. L. Myers, and K. Yee, Probability and Statistics for Engineers and Scientists, 8th Edition. Boston: Prentice Hall, 2011.

[24] Indrawati, Metode Penelitian Manajemen dan Bisnis. Bandung: Refika Aditama, 2015.

[25] Azwar, Reliabilitas dan Validitas: Seri Pengukuran Psikologi. Yogyakarta: Sigma Alpha, 2012.

[26] D. Deniz, 'Effects of Perceived Safety on Women Mobility Habits for Sustainable Public Transportation', American International Journal of Social Science, vol. 5, no. 4, pp. 85-93, Aug. 2016.

[27] C. Duchène, 'Gender and Transport', International Transport Forum Discussion Paper, vol. 2011, no. 11, 2011.

[28] Grab, 'Aplikasi tidak bisa terbuka, tiba-tiba tertutup atau muncul kode erorr', Grab Official Website. [Online]. Available: https://help.grab.com/passenger/id/115006437907-Aplikasi-tidak-bisa-terbuka,-tiba-tiba-tertutup-atau-muncul-kode-eror. [Accessed: 01-Apr-2019]. 